\title{
UM OLHAR CRÍTICO SOBRE O CONTO
}

http://dx.doi.org/10.11606/issn.2237-1184.v0i26p37-55

\section{Cleusa Rios P. Passos ${ }^{1}$}

Universidade de São Paulo (USP)

\section{RESUM0}

O ensaio sublinha a importância da contribuição de Boris Schnaiderman para a crítica literária, centrando-se num aspecto preciso: as nuances de seu olhar sobre o aporte dos escritores russos para o conto moderno. Dentre seus artigos relativos, especificamente, ao assunto, três escritos são aqui recobrados: sua obra Dostoiévski. Prosa Poesia. "O senhor Prokhartchin”, o prefácio à tradução de Khadji-Murát, de Tolstói, e o posfácio, publicado na coletânea A dama do cachorrinho e outros contos, de Tchekhov, no qual Schnaiderman assinala o modo singular de compor do autor russo, fundamental à contística moderna e ainda presente na contemporaneidade.

\section{ABSTRACT}

This essay emphasizes de great contribution of Boris Schnaiderman to the studies of literary criticism regarding some exact aspects: the nuances of his critical view on modern Russian short stories. Among his articles related to this subject it is highlighted three studies: Dostoiévski. Prosa Poesia. "O senhor Prokhartchin", and the preface to his Tolstói's translation of KhadjiMurat. This reading also includes an afterword written to a selection of Tchekhov's stories named A dama do cachorrinho e outros contos in which Schnaiderman distinguishes Russians peculiar way of creative imagination of fundamental importance to the modern theory of short stories and that still prevails in our contemporary days.

\section{PALAVRAS-CHAVE:}

Conto moderno;

Formas literárias;

Poe;

Tolstói;

Dostoiévski;

Tchekhov.

\section{KEYWORDS:}

Modern short story;

Literary forms;

Poe;

Tolstói;

Dostoiévski;

Tchekhov.

\footnotetext{
${ }^{1}$ Professora titular do Departamento de Teoria Literária e Literatura Comparada - FFLCH-USP
} 
"As pessoas não morrem, ficam encantadas".

João Guimarães Rosa

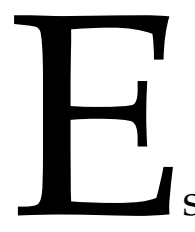

ssa epígrafe constitui uma das renomadas frases do discurso de posse de Guimarães Rosa, na Academia Brasileira de Letras, e pode se estender ao Prof. Boris Schnaiderman, pois seu encanto permanece no legado fundamental das traduções de grandes escritores russos, permitindo que se tenha acesso, com prazer e confiabilidade, a textos ficcionais/poéticos de Dostoiévski, Púchkin, Tolstói, Tchekhov, Górki etc. Ele deixa igualmente poemas traduzidos em parceria com Haroldo e Augusto de Campos, consolidando a amplitude de suas pesquisas, dedicadas à língua, à história e a agudos estudos críticos; à guisa de exemplo, cabe citar seu texto memorialístico, Guerra em surdina, que enfoca a trilha dos combatentes da Força Expedicionária Brasileira, além de artigos sobre diversos escritores, dentre eles, M. Bakhtin. Ao lado dessa variada obra, responsável pela larga divulgação da cultura russa no Brasil, Boris Schnaiderman dava lição de vida acadêmica, incentivando publicações de escritos e teses de docentes e alunos, em revista e livros, realizando finas arguições em bancas e concursos, sempre com respeito, erudição, e contida delicadeza, também manifestos no atendimento de quem o procurava para dúvidas e orientações. E, aí, me integro, pois, faço parte daqueles que lhes serão sempre gratos e que reconhecem a importância de propagar sua produção a outros leitores.

A presença lúcida de Schnaiderman permanece, inclusive, em inúmeros ensaios críticos, relativos a diferentes assuntos; dentre eles, vale recobrar dois de seus escritos, concernentes ao conto moderno. O primeiro, o livro Dostoivéski. Prosa Poesia, publicado em 1982, é o resultado de sua livre-docência, defendida em 1974 e centrada no conto, até então pouco conhecido, "O senhor Prokhartchin"; o segundo, posfácio da coletânea $A$ dama do cachorrinho e outros contos, obteve até o momento quatro edições (1956, 1985, 1986 e 1999), consistindo na escolha e tradução de contos de Tchekhov. Os dois trabalhos colaboram, cada um a seu modo, para a compreensão e para os desdobramentos teóricos da contística ocidental. Vamos a eles. 


\section{Um conto a ser lembrado}

Desde o título, Dostoiévski. Prosa Poesia revela um enfoque voltado para a tradição da mistura de formas literárias, traço comum no escritor abordado por Schnaiderman, com o intento de enfatizar o caráter poético da criação de Dostoiévski, que se considerava mais "poeta" do que "romancista ou escritor" 2 . Nesse sentido, é valiosa a opção pelo conto "O senhor Prokhartchin" para ser traduzido e analisado, salientando-se o lirismo de sua linguagem, particularmente implícito nos romances do autor russo. A interpretação textual leva o leitor a perceber, no mínimo, dois olhares em Schnaiderman: o do tradutor e docente minucioso preocupado com a clareza imprescindível ao público brasileiro, pouco familiarizado com os sons da língua russa, e com o esclarecimento de "dilemas" da passagem da língua (e cultura) de partida à de chegada; e o do ensaísta e crítico literário - consciente da necessidade da contextualização da narrativa e atento a sua recepção, resgatada pela pesquisa da fortuna crítica relativa ao escritor.

Esses caminhos já indicariam uma maneira de abordar a criação literária (não por acaso, o capítulo do livro que trata dos aspectos mencionados recebe o nome de "Vias de penetração no conto"), mas, há também o acréscimo da polifonia, tão peculiar aos romances de Dostoiévski e visível em "O senhor Prokhartchin". Aí, instauram-se o jogo sério-cômico, a abolição das fronteiras definidoras do "gênero" e a mescla entre tom elevado e baixo, fundamental à sátira menipeia, comprovando a afirmação de Bakhtin, segundo a qual "elementos de menipeia" se apresentam desde as primeiras obras de Dostoiévski, embora o pensador russo não se refira a esse conto de 1846. O estudo de Schnaiderman examina as questões sublinhadas e, ainda, apreende o processo inventivo do ficcionista a partir do tom, da construção das personagens, de suas vozes, o apuro verbal, revelador de relações líricas entre som e sentido, procurando rastrear a singularidade do texto e seu papel no conjunto da produção posterior de Dostoiévski.

Cabe lembrar que, no século XIX, a discussão sobre a forma "conto" e suas fronteiras ganha força, porque, particularmente no período de 1842 a 1847, Edgar Allan Poe estava às voltas com as configurações formais do poema, estendendo-as à narrativa curta e sistematizando suas ideias em dois reconhecidos ensaios, "A filosofia da composição", no qual expõe o processo de construção de seu "The raven", e "Hawthorne", em que discute a originalidade criativa desse escritor e defende a brevidade do conto em função do "efeito único ou singular", ligado a um desígnio

\footnotetext{
2 SCHAIDERMAN, Boris. Dostoiévski. Prosa Poesia. "O senhor Prokhartchin". São Paulo: Perspectiva, 1982, p.108.
} 
preconcebido, na busca da impressão de totalidade a ser despertada no leitor ${ }^{3}$.

Contudo, o conto de Dostoiévski segue trajetória diversa - sem se prender a regras preestabelecidas à maneira de Poe - e análoga a vários escritores, uma vez que, ainda hoje, há dificuldade em se determinar os limites da forma literária aqui discutida. De um lado, "O senhor Prokhartchin" parece manter essa herança quanto à dubiedade de extensão (poderia ser uma novela...), de outro, seu autor recria a tradição, ao retomar aspectos da sátira menipeia, em época e espaço distintos. Parte da crítica considera o texto desarticulado e, no "Prólogo Geral" à publicação de Novelas de juventude de Dostoiévski, Natalia Nunes adverte que a leitura da narrativa se faz lacunar, gerando a sensação de fragmentos ausentes, como se a "história flutua[sse] num ambiente de torvelinhos desarticulados". Schnaiderman cita a passagem com o intento de pôr em dúvida esse ponto de vista, indagando se não haveria, no conto, um modo de articulação pouco comum à época, ou seja, um enredo que romperia a "sequência temporal consagrada", algo encontrado em "muitas obras modernas", evocando, por exemplo, Ficciones de Borges" ${ }^{4}$ O crítico aponta também a importância do sério-cômico "para a gênese da ficção moderna", conforme destaca Bakhtin, $\mathrm{n}^{\prime}$ A obra de Rabelais e a cultura popular da Idade Média e do Renascimento.

Em "O senhor Prokhartchin", tal aspecto se desenvolve "passo a passo com a multiplicação de vozes" 5 , pois, o narrador vai capturando a opinião dos hóspedes da pensão em que mora a personagem principal, dando menor enfoque ao que ela própria pensa. Certas passagens justificam o processo de "dialogização", revelando que "A palavra não vale por si, mas pela repercussão que provoca em outros indivíduos do mesmo contexto." 6 . A presença de vozes peculiares assinala diferentes perspectivas; nas palavras, o sentido direto pode não ser o único, ou seja, elas podem ressoar sentidos discordantes da compreensão aparentemente conclusiva. A própria voz narrativa é questionada em relação aos fatos

\footnotetext{
3 Já apontei, no ensaio "Breves considerações sobre o conto moderno" (BOSI et al., 2001, p.6790)., que não se pode esquecer o aflorar da ideia em outros contextos. Por exemplo, tanto Goethe, em "Entretiens d'émigrés alemands" (publicado em Die Horen (1795), revista organizada por Schiller), como Hoffmann, em seus Contos de Serapião (1819-1821), constroem personagens que comentam seus tipos de composições preferidas. No primeiro autor, um participante de uma roda de histórias diz apreciar narrativas apoiadas em poucos e claros personagens e acontecimentos, algo alusivo a certa unidade de sentido. Quanto a Hoffmann, uma de suas figuras ficcionais argumenta gostar mais de contares feéricos, sustentados por "um fio elegante e firme" e não pela multiplicidade de traços "fantásticos", sugerindo a presença de um "núcleo sólido" como elemento fundamental ao narrar.

${ }^{4}$ SCHNAIDERMAN, Boris - Dostoiévski. Prosa Poesia. "O senhor Prokhartchin". São Paulo:

Perspectiva, 1982. p.67

5 Op.cit., p.72.

${ }^{6}$ Op.cit., p.74.
}

40|BORIS SCHNAIDERMAN: Ensaios 
ligados a Prokhartchin, pois, se essa voz parece aderir às ideias dos inquilinos, ela ironiza igualmente a "mesquinhez" que os caracteriza.

Schnaiderman aí captura a configuração dos hóspedes, da senhoria, do contexto social e, particularmente, das várias vozes que funcionam como "alternância" do sério e do cômico, da estilização do trágico e do grotesco, contaminados pelo cômico, juntamente com a atmosfera paródica, envolvendo poemas do romantismo ${ }^{7}$. E o faz pensando em elos com Bakhtin e na análise da sucessão temporal, ancorada no conceito de durée bergsoniana. Com o intento de fundamentar o jogo de cortes dos acontecimentos e do fluxo interior, elaborado no conto, Bergson ${ }^{8}$ é literalmente citado - "a aparente descontinuidade da vida psicológica se deve a que a nossa atenção se fixa sobre ela por uma série de atos descontínuos"9-, para ancorar, em parte, as variações do narrador de "O senhor Prokhartchin" que, ora se mostra onisciente, ora suspende fatos e esclarecimentos, ora faz intromissões vagas, deixando entrever que alguma coisa flui atrás dos fatos descritos e escapa aos olhos do leitor. Curiosamente, tal expediente parece recorrente em Dostoivéski.

O recurso sugere uma espécie de vai e vem entre alusões ao fluxo interior dos seres ficcionais, no qual se inserem os traços descontínuos, e o exterior, espaço dos acontecimentos cotidianos e supostamente mais contínuos. E, ainda, a leitura não só retoma Bergson, mas considera também que pesquisas modernas da física lançam luz sobre a narrativa, tornando-a menos "confusa" ou enigmática; isto é, a partir de outros saberes, produzidos em contexto histórico distinto, Schnaiderman ressalta questões, não avaliadas na época do lançamento do conto, que merecem reexame e permitem relativizar a opinião de alguns críticos, anteriormente disseminada.

A favor de sua tese, é possível, em meio a outras reflexões culturais, revisitar as propostas de Freud, referentes ao funcionamento psíquico, à memória e, em particular, ao paradoxal pensamento sobre a temporalidade, esboçado desde seu Projeto para uma psicologia científica (1895), antes de L'évolution créatrice (1907), de Bergson, utilizada como referência no texto de Schnaiderman. Conforme se sabe, na concepção freudiana, o tempo do inconsciente obedece a uma lógica própria, diversa do tempo cronológico, e atua na reconstrução das lembranças, reelaborando e recriando traços do passado no presente.

Esse processo ocorre "a posteriori", pois, as marcas mnêmicas de outrora podem ser ressignificadas em outro instante da vida, num "só

\footnotetext{
7 SCHNAIDERMAN, Boris - Dostoiévski. Prosa Poesia. "O senhor Prokhartchin". São Paulo: Perspectiva, 1982. p.82.

${ }^{8}$ Cabe sublinhar que se trata de sua obra L'évolution créatrice (1907).

9 SCHNAIDERMAN, Boris - Dostoiévski. Prosa Poesia. "O senhor Prokhartchin". São Paulo: Perspectiva, 1982. p.90.
} 
depois" não submetido à cronologia convencional. Guardadas as devidas diferenças entre a interpretação da psicanálise e a da literatura, e sempre por meio de analogias, o distanciamento temporal da leitura de uma obra também permite ressignificá-la. É o caso da interpretação apresentada em Dostoiévski. Prosa Poesia. Se "O senhor Prokhartchin" não está entre as grandes obras do ficcionista, Schnaiderman o relê não só ressaltando aspectos atuantes no conjunto da produção de seu autor, mas evidenciando princípios de sua fatura, peculiares à escrita e à multiplicidade de formas que o conto assume no universo literário moderno e que se desdobram no contemporâneo.

Diversos pesquisadores de sua época compartilham tais desdobramentos. À guisa de exemplo, veja-se a introdução de Alfredo Bosi a seu $O$ conto brasileiro contemporâneo, na qual, ao buscar os caminhos seguidos por contistas específicos de nossa literatura, ele acaba indo além dela, no que concerne à teoria do conto, ao afirmar: "se comparado à novela e ao romance, a narrativa curta condensa e potencia no seu espaço todas as possibilidades de ficção", pondo "em jogo os princípios de composição que regem a escrita moderna em busca do texto sintético e do convívio de tons, gêneros e significados." 10 . Não é outro o olhar crítico de Schnaiderman a respeito da questão.

\section{Tchekhov e a forma "conto" no contexto russo}

Tal pensamento se confirma no posfácio da quarta edição da coletânea A dama do cachorrinho e outros contos, de Tchekhov, uma vez que Schnaiderman volta à teoria do conto, reexamina o que já escrevera, reitera o papel dos ficcionistas russos na "subversão do consagrado", em se tratando de formas literárias, e insiste que a subversão de Tchekhov [...]"tinha muito de russo, pois na Rússia os padrões ocidentais de gênero eram aceitos, mas, ao mesmo tempo, havia uma resistência que acarretava flutuação e afastamento [...]"11

Desde Púchkin, os exemplos de distância da "forma europeia" se multiplicam, constata o crítico, pois os referidos padrões ocidentais chegam à Rússia, porém são assimilados de modo paradoxal, provocando "atração e repulsa" em seus autores, que procuram afirmar "algo muito diferente." Nesse sentido, Schnaiderman reforça a postura resistente de Tchekhov e a conveniência de se assinalar a importância da cultura específica de seu povo, além do fato de que, até o século XVIII, as obras consideradas literariamente "dignas" terem sido escritas em eslavo

\footnotetext{
10 BOSI, Alfredo (org.) - O conto brasileiro contemporâneo. São Paulo: Cultrix, 1977. p. 7.

11 TCHEKHOV, Antón - A dama do cachorrinho e outros contos. Tradução e Posfácio de Boris Schnaiderman. São Paulo: editora 34, 1999. p.334.
} 
eclesiástico ${ }^{12}$. Graças ao conhecimento da história e da literatura russa, ele também reaviva, em seu artigo "Tolstói: antiarte e rebeldia" (1983), dedicado a esse outro autor, uma frase conhecida do criador de Guerra e paz: "A forma romance acabou." (1893).

Ainda no ano de 1893, Tolstói recupera a declaração, num diário, argumentando: "A forma do romance não só não é eterna, mas ela está acabando. Dá vergonha escrever mentiras, que aconteceu aquilo que não houve. Se você quer dizer algo, diga-o diretamente."13. Embora aflore na observação a perspectiva moral, sabe-se que conteúdo e forma não se separam, logo, a mudança daquele acarreta a desta. Como o interesse aqui é teórico, não é difícil estender a posição de Tolstói às narrativas curtas, tão imaginárias quanto o romance, especialmente, se atentarmos para sua reflexão sobre o próprio papel de ficcionista. Diz ele a respeito de uma de suas obras mais renomadas: "O que é Guerra e paz? Não é um romance, ainda menos um poema, e ainda menos uma crônica histórica. Guerra e paz é aquilo que quis e pôde expressar seu autor, na forma em que foi expresso."14.

Vale, agora, recobrar a oscilação entre "afastamento" e "flutuação", mencionada anteriormente, pois ela permite perceber a paradoxal recepção da tradição europeia no universo da literatura russa. O primeiro termo é de pronto compreensível, mas faz pressupor, na procura de uma simetria mais corrente, o vocábulo "aproximação", entretanto, este é deslocado por "flutuação", sugerindo o acatamento de certas noções teóricas modernas e, paralelamente, um movimento contrário, o de não adesão estrita dos autores russos a normas de fora, no caso, as de Edgar Allan Poe. Para eles, resistir seria não abdicar do ato criativo, que pode incorporar ou ir além das propostas do escritor norte-americano em relação à modernidade da narrativa breve e, aqui, interessa, especialmente, a perspectiva de Tchekhov em relação a tal narrativa.

Obter o efeito único ou singular de Poe, tendo por meta um conto "bem feito", construindo um enredo que, desde o início, deve combinar incidentes em função de seu desenlace pode ocorrer em composições específicas de Tchekhov, porém, em muitas outras, o "desfecho" se mostra diverso, insinuando, conforme a crítica, uma espécie de "anti-desfecho" pela continuidade da situação imaginária e suspensão de um final demarcado. A postura do autor parece se espraiar no conjunto de sua obra. Ele próprio escreve em carta: "Eu tenho entrecho interessante para uma comédia, mas ainda não atinei para o final. Quem inventar novos finais de

12 TOLSTÓI, Lev - Khadji-Murát. Tradução e Posfácio de Boris Schnaiderman. São Paulo: editora 34, 2017. p. 210.

${ }^{13}$ apud Op.cit., p.218.

14 apud Op.cit., p.210.

43|BORIS SCHNAIDERMAN: Ensaios 
peça há de inaugurar uma nova era. [...]". ${ }^{15}$. No fim da passagem, com o intento de ressaltar a mistura de formas, realizada por Tchekhov em várias produções, Schnaiderman engata outro fragmento epistolar, referente ao término de A gaivota, no qual ele declara: “Bem, a peça eu já concluí. Comecei-a em forte e terminei em pianíssimo - ao revés de todas as regras da arte dramática. Saiu-me uma novela. [...]" 16.

Conforme se observa, na constatação aflora a recusa a se submeter a um "desígnio" preconcebido, ao menos em termos formais. Embora o escritor esteja tratando de comédia-drama / novela, ele revela rejeitar amarras fixas quando cria, inserindo-se aí a narrativa breve. Convém ressaltar, de acordo com Schnaiderman, que Tchekhov hesita, às vezes, diante dos "resultados novos" e da contribuição à crítica literária relativa a sua criação. Inegável que, ao invés de fechar caminhos, ele abre vários. É possível deduzir que, ao tratar do conto, o artista russo se afasta da intenção rigorosa de Poe de sujeitar "a alma do leitor", seu imaginário, ao "propósito" do autor, "durante a hora de leitura". Anos depois, observase, ainda, no ensaio "Poe: o poeta, o narrador e o crítico" constatação parecida por Julio Cortázar: "Poe escreverá seus contos para dominar, para submeter o leitor no plano imaginativo e espiritual" 17.

Cabe, então, refletir a respeito da modernidade de Tchekhov, que não se priva de construir textos breves, articulando "incidentes", para produzir determinados efeitos acerca de "um "problema" e de uma "intenção", considerando-os traços fundamentais ao ato criativo. A isso se acrescenta que, caso um autor lhe declarasse escrever uma narrativa "sem intenção premeditada, apenas por inspiração", ele o chamaria de louco ${ }^{18}$. Ora, se há traços análogos nas concepções de Poe e Tchekhov, há igualmente diferenças. O ficcionista russo propõe escrever sobre um problema, não lhe dar solução final. Em carta, adverte que não se pode confundir "[...] a solução do problema e a colocação correta do problema. Apenas o segundo é obrigatório para o artista."19. Para ele, a intenção necessária ao trabalho inventivo pode se elaborar sem um desenlace definitivo, sugerindo, em seu lugar, suspensão e seguimento.

\footnotetext{
${ }^{15}$ apud TCHEKHOV, Antón - A dama do cachorrinho e outros contos. Tradução e Posfácio de Boris Schnaiderman. São Paulo: editora 34, 1999. p.335.

16 apud Op.cit., p.336.

17 Aqui se optou pelas traduções (em geral, reconhecidas oficialmente) de todos os textos para o português, em nome da uniformização das citações. (Cortázar, 1974, p.121).

${ }_{18}^{18}$ apud ANGELIDES, Sofia.- A.P.T Tchekhov: cartas para uma poética. São Paulo: Edusp, 1995. p. 104.

${ }^{19}$ apud ANGELIDES, Sofia.- A.P.T Tchekhov: cartas para uma poética. São Paulo: Edusp, 1995. p. 104.
} 
Com olhar distinto e, sem dúvida, fulcral para a modernidade, já o contista norte-americano cria "estruturas fechadas e completas" 20 . Se é plausível relativizar a ideia, é difícil recusá-la inteiramente, pois ela ocorre em grande parte de suas produções. De maneira similar à proposta de Poe, o autor russo defende a brevidade da obra, em vários fragmentos epistolares. Um desses excertos, o conhecido conselho de Tchekhov ao irmão, em 1889, merece ser transcrito: “A concisão é irmã do talento [...]. O enredo deve ser novo, ao passo que a fábula pode estar ausente. [...]" ${ }^{21}$. Contudo, em linhas gerais, o autor de "A dama do cachorrinho" escapa tanto à busca do fato excepcional, estranho ou inquietante - preferindo enfocar aspectos do cotidiano, da opressão socioeconômica, da angústia e da compaixão humana - como a normas prefixadas à maneira de Poe.

Schnaiderman aponta tal atitude de Tchekhov, ao ter a sagacidade de selecionar diferentes contos para traduzir em sua coletânea, incluindo até os que o próprio autor eliminara de suas obras completas, ou seja, ao olhar do tradutor se incorpora o do crítico literário em busca da divulgação do conjunto da contística em pauta e do ato diversificado de narrar, opondo-se, com justeza, ao argumento de alguns, segundo o qual Tchekhov estaria "treinando a pena" nos textos omitidos - daí a supressão -, permitindo que sua leitura circulasse entre nós. Quatro deles são contemplados no livro, a saber, "Pamonha", "Um dia no campo", "Fantasiados" e "Nos banhos". Se observados mais de perto, descobre-se que comportam temas recorrentes e a visão de mundo do ficcionista, manifestos, em grande parte, dos escolhidos "oficialmente". Em todos, atuam a correlação entre narrativa e vida, a concisão e o dado coloquial expresso em "tom menor", características bem sublinhadas no posfácio de A dama do cachorrinho e outros contos.

"Pamonha" e "Um dia no campo" focalizam figuras humildes e oprimidas (uma governanta, um bêbado e duas crianças órfãs). "Fantasiados" remete a Máslienitza, feriado russo semelhante ao Carnaval, construindo um reiterado mascaramento de personagens anônimas, com perfis, profissões, idades e classes sociais distintas, espelhos de uma contradição entre o que a máscara camufla e o que sob ela se desvenda: um professor, aparentemente só dedicado à ciência, tem em vista interesse financeiro; uma mulher, rica e feliz, está a ponto de ser substituída por outra e tudo perder; um advogado defende a pobre cliente como se fosse um poeta, mas poderia acusá-la, se lhe pagassem melhor...etc. Por fim, "Nos banhos" gira em torno de uma conversa sobre o ajuste de casamento das mulheres e os dotes oferecidos pelos pais, reunindo-se a outros textos

${ }^{20}$ CORTÁZAR, Julio - Valise de Cronópio (trad. Davi Arrigucci Jr e João Alexandre Barbosa: org.

Haroldo de Campos e Davi Arrigucci Jr). São Paulo: Perspectiva, 1974. p. 135.

${ }^{21}$ apud ANGELIDES, Sofia.- A.P.T Tchekhov: cartas para uma poética. São Paulo: Edusp, 1995. p. 136. 
na denúncia social, indicativa seja do deslocamento dos laços afetivos por financeiros, seja da submissão da mulher ao comércio entre pais e noivos.

Bastam poucos exemplos para lançar luz sobre a pertinência da seleção de Schnaiderman: as duas primeiras narrativas vinculam humildade, resignação e lirismo, aliando-se a várias criações de Tchekhov, reconhecidas pela crítica. Dentre tantas, veja-se "Angústia", centrada na dor de Iona, um cocheiro que precisa falar para construir seu processo de luto pela morte do filho. A família distante, o crepúsculo e os lampiões "recém-acesos", a neve intensa constituem paisagem e cenas inóspitas, sugestivas da solidão que leva a personagem a se encolher no próprio corpo, inteiramente branco, e com ele encolher também a fala, enquanto percorre as ruas, recebendo passageiros que o ignoram, pagam-lhe pouquíssimo e não se dispõem a escutá-lo. A denúncia da insensibilidade e da correria do universo urbano se intensifica no profundo desamparo do cocheiro, que precisa verbalizar a angústia, sem pressa, expondo as cenas anteriores à perda de seu sucessor de ofício e geração (a doença, o sofrimento, a ida ao hospital, o enterro etc.), a ponto de o narrador constatar: "Vai fazer uma semana que lhe morreu o filho e ele não conversou direito com alguém sobre aquilo... É preciso falar com método, lentamente..." 22 .

A lentidão, o "método" são indispensáveis, pois dizem respeito ao modo pelo qual a palavra faz aflorar as lembranças, permite o curso da dor e a instauração do trabalho de luto - o "trabalho psíquico da perda" - que precisa de tempo para que a personagem (o "eu") renuncie ao objeto amado e se reconstrua na relação com o objeto perdido - o filho que se torna imagem interior para o pai. Nesse sentido, a conclusão de "Angústia" não é cabal, ela indica a continuidade da vida cotidiana, uma vez que Iona apenas começa seu processo de luto, mantendo-se solitário e sem entrever perspectivas de mudança em suas relações sociais. É certeira a observação de Schnaiderman: "Frequentemente, o contista retoma os grandes temas da literatura russa e explora-os justamente num tom menor [...] Os grandes temas estão muitas vezes, parece insistir o contista, nas coisas pequenas, nos episódios que parecem sem importância" 23. O desfecho (ou antidesfecho?) do drama de Iona reforça a resignação humana do homem humilde, já apontada em "Pamonha" e em "Um dia no campo": ao cocheiro só restam os ouvidos de sua eguinha, com quem busca identificação afetiva ("Agora, vamos dizer, você tem um potrinho, que é teu filho... E, de repente, vamos dizer, esse mesmo potrinho vai para o outro mundo... Dá pena, não é verdade?) e, enfim, "anima-se e conta-lhe

\footnotetext{
22 apud TCHEKHOV, Antón - A dama do cachorrinho e outros contos. Tradução e Posfácio de Boris Schnaiderman. São Paulo: editora 34, 1999. p.137.

${ }^{23}$ TCHEKHOV, Antón - A dama do cachorrinho e outros contos. Tradução e Posfácio de Boris Schnaiderman. São Paulo: editora 34, 1999. p.337.
} 
tudo..." 24. De maneira impecável, Tchekhov reúne humildade, carência social e grandeza de sabedoria da personagem, sujeita a uma terrível dor humana, num texto que escapa, sem dúvida, às fronteiras espaciais da Rússia e à época de sua publicação.

Quanto a "Fantasiados" e a "Nos banhos", ambos destacam um veio insistente em Tchekhov, manifesto no igualmente conhecido "Bilhete premiado" que Schnaiderman analisa no posfácio, destacando, mais uma vez, questões como a concisão, a condição social, a vida medíocre dos seres ficcionais e o aspecto temporal da narrativa, marcada pela diferença entre a duração cronológica dos acontecimentos e duração da vida psíquica, ao lado de uma subversão fundamental: a esperada tensão do desfecho se concentra no "miolo" do conto. O crítico assinala a "contradição de sentimentos" das personagens, que vão do "encantamento" do devaneio, gerado pela esperança de a mulher ter seu bilhete de loteria premiado, até a desilusão do sonho não concretizado. A angústia do marido - e, segundo Lacan, a angústia é um afeto que não engana - desencadeia traços inesperados da verdade de sua infeliz vida cotidiana, a ponto de considerar a mulher inimiga. Análogo aos dois contos não publicados nas obras completas, também neste o interesse financeiro contamina as relações conjugais, revela afetos encobertos e a melancólica pequenez humana.

Cada um dos quatro textos comporta, ainda, expressivos procedimentos composicionais, indicativos da abertura do "conto", que tanto pode abarcar qualquer tema romanesco dentro de seus limites físicos, como traços de diferentes formas literárias. Em "Pamonha”, um diálogo dramático com a governanta vai crescendo e intensificando o mal-estar causado pela aparente tirania do patrão, que testa a tolerância da humilde mulher, no momento do acerto de contas. De igual modo, "Nos banhos" se faz por meio de diálogos, majoritariamente, irônicos e construídos em torno de regras sociais sobrepostas às afetivas, num ambiente no qual os corpos desnudos propiciam o desnudamento da palavra e de traços da sociedade. "Um dia no campo" se sustenta na mescla dos tons lírico e prosaico no ato de narrar, graças à história de um frágil orfão, entusiasmado com pequenas descobertas da natureza, despertadas por um homem também desvalido (de novo, a ironia!), porém empenhado em abrandar o desamparo da criança. "Fantasiados" reúne fragmentos nos quais as máscaras dos seres ficcionais se encadeiam, evocando aspectos de outro recurso de comunicação, designado por "faits divers" no jargão jornalístico. Nas quatro narrativas, recobradas pelo olhar crítico de Schnaiderman, cai como uma luva a conclusão de Bosi a respeito da "escrita moderna" (concernente ao conto), pois, nelas, coexistem a concisão, "o convívio de tons, de gêneros e significados".

24 apud Op.cit., p.138.

47|BORIS SCHNAIDERMAN: Ensaios 


\section{Ecos da criação russa na teoria do conto}

Em linhas gerais, os ensaios de Boris Schnaiderman sobre os textos de Dostoiévski, Tolstói e Tchekhov (além de outros não contemplados aqui) contribuem para alargar a percepção tanto da mistura das formas literárias, como da teoria do conto na modernidade, estendendo-se à crítica atual. Os três ficcionistas mencionados questionam noções teóricas, cujas dúvidas perduraram no panorama da literatura ocidental. No Brasil, elas ressoam, por exemplo, em Mário de Andrade, que revela preocupação próxima à de Tolstói 25 sobre os vínculos entre construção ficcional (romance, em seu caso) e verdade, ao iniciar "Vestida de Preto", integrante de Contos Novos, com a observação: "Tanto andam agora preocupados em definir o conto que não sei bem si o que vou contar é conto ou não, sei que é verdade." 26. A postura de Tolstói a respeito de Guerra e Paz (segunda a qual o autor teve a liberdade de expressar o que quis na "forma que o expressou") também ecoa na do escritor brasileiro, no ensaio "Contos e Contistas", escrito em 1938. Argumenta Mário: "Em verdade, sempre será conto aquilo que seu autor batizou com o nome de conto"27.

Guimarães Rosa segue trilha semelhante em Corpo de baile (1956), obra considerada pela crítica "ciclo novelístico", mas nomeada de maneira variada pelo escritor. Em sua segunda edição (1960), lançada pela José Olympio num só volume, aparece o título e, sob ele, entre parênteses, a expressão "(sete novelas)"; na página seguinte, sob o título, surge a designação "Os poemas" e o elenco dos seus sete nomes. Encerra o tomo uma divisão em dois momentos: "GERAIS", contendo quatro dos títulos anteriormente mencionados e, entre parênteses, a conceituação ("Os romances"): "Campo Geral", "A estória de Lélio e Lina", "Dão-Lalalão" e "Buriti", e "PARÁBASE", compreendendo os três títulos restantes e a conceituação: ("Os contos"): “Uma estória de amor", "O recado do morro" e "Cara-de-bronze". Igualmente a cargo da José Olympio, a terceira edição (1964) se desmembra em três volumes, ocorrendo novo desdobramento compositivo: as quatro narrativas constituintes dos tomos Manuelzão $e$ Miguilim ("Campo Geral" e "Uma estória de amor") e Noites do sertão ("Lão-Dalalão (Dão-Lalalão)" e "Buriti") são consideradas poemas, duas outras integrantes de No Urubùquaquá, no Pinhém ("O recado do morro" e "Cara-de-bronze") denominam-se contos e uma terceira ("A estória de Lélio e Lina") romance.

Conforme se vê, não só se ignora a convencional classificação de "gêneros", mas não se permitem categorizações definitivas, graças ao deslocamento - numa mesma edição (caso da segunda) ou de uma para

${ }^{25}$ Cf. citação da p. 6.

${ }^{26}$ ANDRADE, Mário - Contos Novos. São Paulo/Brasília: Martins/INL, 1972. p.7.

${ }^{27}$ ANDRADE, Mário - O empalhador de passarinho. São Paulo/Brasília: Martins/INL, 2002.p.9. 
outra (segunda para terceira e subsequentes) - das formas literárias, estabelecendo-se um embaralhamento terminológico e, depois, uma lúdica troca de perspectiva que atravessa as narrativas, ressaltando-se as famosas misturas de Rosa, isto é, o prosaico e o lírico se contaminam e a extensão deixa de ser um aspecto clássico para conceituar a obra. Incorporam-se às misturas, embora Rosa não o explicite, intensos indícios da dramática, permeando em maior ou menor grau, suas invenções; basta ler "Cara-debronze". Em suma, o deslizamento das formas obriga o leitor a repensar a leitura de cada texto, indo além da concepção de novela que já encerra em si complexas questões, relativas a suas fronteiras com o conto e o romance.

Outro elo da cadeia de recusa a teorias formais rigorosas ocorre com Julio Cortázar, em "Alguns aspectos do conto", produto de uma conferência realizada em Cuba, logo após a revolução e publicado em 1963 pela Casa de las Americas. O artigo comporta algo dos autores citados e, em última instância, da relação entre a maneira de se apreender o mundo e os "gêneros literários":

[...] minha própria maneira de entender o mundo explicará minha tomada de posição e meu enfoque do problema. Em último caso poderá dizer que só falei do conto tal qual eu o pratico. E, contudo, não creio que seja assim. Tenho a certeza de que existem certas constantes, certos valores que se aplicam a todos os contos, fantásticos ou realistas, dramáticos ou humorísticos. ${ }^{28}$.

$\mathrm{O}$ argumento poderia ser o de Rosa e, sem dúvida, lembra o de Tolstói, isto é, a prática da escrita vai além dos paradigmas teóricos convencionais e, se Cortázar expõe tal visada, é porque tem por antecessores Poe e Tchekhov, revisitando-os e discutindo suas concepções com o intento de marcar a própria direção. Logo, é preciso reconhecer a importância da liberdade ficcional e da perspectiva de cada um, pois, se Poe cria uma das propostas normativas fundamentais para o conto moderno, os autores russos 29 , ao mesmo tempo em que compartilham a noção de brevidade de tais narrativas, rejeitam algumas das regras enumeradas pelo norte-americano. Representante de tal "vertente", Tchekhov é retomado, uma vez que esclarece, em cartas, seu pensamento a respeito do ato inventivo, valorizando a concisão, sem abdicar da autonomia de seu "ofício", que, se delimita regras composicionais, também admite alterá-las ao longo da elaboração criativa, sabendo-o ou não... Em

\footnotetext{
${ }^{28}$ CORTÁZAR, Julio - Valise de Cronópio (trad. Davi Arrigucci Jr e João Alexandre Barbosa: org. Haroldo de Campos e Davi Arrigucci Jr). São Paulo: Perspectiva, 1974. p.149.

${ }^{29}$ Vale assinalar que o recorte deste ensaio privilegia a contribuição de alguns russos para a teoria do conto moderno e, particularmente, a de Tchekhov. Não se ignoram as lacunas de tal escolha em se tratando do aporte de grandes escritores de outras literaturas para o assunto.
} 
sua carta sobre A gaivota ${ }^{30}$, o escritor reconhece que, ao produzir um texto, não escapa inteiramente de ser produzido por ele...

Assim, ecos de Poe e Tchekhov surgem em vários críticos e escritores. Dentre estes, Mário de Andrade e Guimarães Rosa constituem exemplos sólidos da ruptura com formas literárias preestabelecidas e é Clarice Lispector quem também reforça, no cenário brasileiro, tal ruptura no interior do texto ficcional, recorrendo ao deslizamento da própria voz narrativa que conduz Água viva, livro escrito em 1973, para impor a soberania do autor no ato da escrita:

\begin{abstract}
Sim, quero a palavra última que também é tão primeira que já se confunde com a parte intangível do real [...]. Que mal porém tem eu me afastar da lógica? Estou lidando com a matéria prima. Estou atrás do que fica atrás do pensamento. Inútil querer me classificar: eu simplesmente escapulo não deixando, gênero não me pega mais ${ }^{31}$.
\end{abstract}

Não só autores brasileiros recusam categorias formais estritas, os sulamericanos o fazem de modo similar; além do já citado Julio Cortázar, merecem atenção o uruguaio Horácio Quiroga e, mais recentemente, o argentino Ricardo Piglia. Os três se aproximam por criar narrativas literárias, discutir - em maior ou menor grau - a teoria do conto, pertencer ao contexto cultural hispano-americano e dar continuidade ao legado de Poe e dos escritores russos. Quiroga publica, em El Hogar (1925), seu "Decálogo do perfeito contista", começando por homenagear a maestria de Poe e Tchekhov: "Crê em um mestre - Poe, Maupassant, Kipling, Tchekhov - como em Deus mesmo." Aconselha, depois: "Não comeces a escrever sem saber desde a primeira palavra aonde queres chegar. Em um conto bem logrado, as três primeiras linhas têm quase a mesma importância das três últimas". O autor uruguaio endossa as reflexões dos antecessores em relação à brevidade, ou seja, o "desígnio preconcebido" de Poe e a "intenção predeterminada" de Tchekhov. No entanto, do primeiro, recusa as regras concernentes ao domínio pleno do ato de criar e recobra parte da visão do segundo, ao recomendar: "Crê que tua arte é um cume inacessível, não sonhes dominá-la. Quando puderes fazê-lo, conseguirás sem o saber."

Quiroga aproveita também dos elos entre "inspiração" e "atitude consciente" 32 , sugeridos pelo autor russo, reconfigurando-os: "Não escrevas sob o império da emoção. Deixe-a morrer e a evoque em seguida. Se fores então capaz de revivê-la tal qual foi, terás chegado em arte à

\footnotetext{
30 Mencionada na p. 7.

${ }^{31}$ LISPECTOR, Clarice - Água viva. São Paulo: Círculo do Livro, 1998. p. 12-13.

32 apud ANGELIDES, Sofia.- A.P.T Tchekhov: cartas para uma poética. São Paulo: Edusp, 1995. p. 103-104.
} 
metade do caminho". E termina tratando de uma das características fulcrais de Tchekhov, ao vincular conto e vida: "Não penses em teus amigos ao escrever, nem na impressão que causará tua história. Conta como se teu relato não tivesse interesse a mais ninguém senão ao pequeno ambiente de teus personagens, dos quais poderias ter sido um. Não há outro modo de se obter vida no conto ${ }^{33}$ ".

Mais tarde, a inquietação com a proximidade entre conto e vida é relembrada por Cortázar. Em outra passagem de "Alguns aspectos do conto", diz ele:

[...] Mas se não tivermos uma ideia viva do que é o conto, teremos perdido tempo, porque um conto, em última análise, se move nesse plano do homem onde a vida e a expressão escrita dessa vida travam uma batalha fraternal, se me for permitido o termo; e o resultado dessa batalha é o próprio conto, uma síntese viva ao mesmo tempo que uma vida sintetizada, algo assim como um tremor de água dentro de um cristal, una fugacidade numa permanência.[...] $]^{34}$.

Ora, Tchekhov busca tais elos, graças a uma concepção de literatura qualificada de "artística porque descreve a vida tal como ela é na realidade", no sentido de que "[...] Na vida não há argumentos. Nela, tudo está misturado - o profundo e o superficial, o grandioso e o significante, o trágico e o cômico" 35. Tais citações são complementadas pelo seguinte arremate, proposto por Sofia Angelides, tradutora e comentadora de trechos de cartas do autor: "Daí também o caráter fragmentário de sua narrativa." 36 , justificando, ainda, que, sobretudo a partir de 1888, Tchekhov seleciona um fragmento da vida de seu herói, penetrando em sua consciência ${ }^{37}$, o que permitiria a apreensão de pensamentos descontínuos e revelaria, aos poucos, a maneira pela qual pequenos fatos cotidianos afetam a ele e a sua vida familiar, sem solução para os problemas desencadeados.

Por fim, merecem destaque algumas afirmações de Ricardo Piglia, que sublinham literalmente a leitura do escritor russo, em "Teses sobre o conto". De início, o crítico anuncia: "O conto é um relato que encerra um relato secreto." 38 , sem considerar que aí se instaura um sentido oculto a depender de interpretação: "o enigma não é outra coisa senão uma história

\footnotetext{
${ }^{33}$ Tradução minha. (Quiroga, 1996, p.1194-1195)

${ }^{34}$ CORTÁZAR, Julio - Valise de Cronópio (trad. Davi Arrigucci Jr e João Alexandre Barbosa: org.

Haroldo de Campos e Davi Arrigucci Jr). São Paulo: Perspectiva, 1974. p. 150-151.

35 apud ANGELIDES, Sofia.- A.P.T Tchekhov: cartas para uma poética. São Paulo: Edusp, 1995. p. 207.

${ }^{36}$ ANGELIDES, Sofia.- A.P.T Tchekhov: cartas para uma poética. São Paulo: Edusp, 1995. p. 207.

37 Op.cit., p.207.

38 PIGLIA, Ricardo - Formas Breves. (trad. José Marcos Mariani de Macedo). São Paulo:

Companhia das Letras, 2004. p. 91.
} 
contada de modo enigmático. A estratégia do relato é posta a serviço dessa narração cifrada" 39 . Sem dúvida, ele recupera a ideia de Poe de que duas histórias correm subjacentes. Aliás, Piglia declara que o conto clássico (Poe e Quiroga) narraria, com todas as letras, em primeiro plano, "a história 1', construindo secretamente a "história 2 nos interstícios da história 1" 40 . Caberia ao contista a arte de cifrar a história dois nos "interstícios" da história um. Para ele: o conto à Poe é considerado "clássico", pois, narra uma história anunciando que há outra, já "o conto moderno conta duas histórias como se fossem uma só." 41 . Ao lado de Katherine Mansfield, Sherwood Anderson e Joyce de Dublinenses, Tchekhov está entre os que transmitem essa "versão moderna" da narrativa breve, configurada tanto pelo abandono do desfecho surpreendente e da estrutura fechada, como pela tensão entre as duas histórias, sem jamais a resolver. ${ }^{42}$

Piglia dá continuidade a tais incursões teóricas em suas onze propostas - algo evocativas do "Decálogo" de Quiroga - nomeadas "Novas teses sobre o conto", cujo intento é buscar outros modos de desfecho para a narrativa curta, tendo por objeto mais constante textos de Borges, que, conforme se sabe, traz uma imensa e variada experiência de leituras e produções finamente singulares. No entanto, importa aqui a constante preocupação com o conto, ao longo da história literária, e a importância de seu desenlace, que, para Piglia, "põe em primeiro plano os problemas da expectativa e nos defronta com a presença de quem espera o relato", não como figura externa à trama, mas como parte dela, ou seja, o autor-ensaísta retoma a ideia segundo a qual o leitor seria uma espécie de "interlocutor implícito"43, graças a textos de Borges e a de diferentes escritores.

Mas, Poe e Tchekov persistem no tempo, afinal, apresentam propostas fundamentais à escrita do conto moderno, reaparecendo no universo literário contemporâneo sob diferentes perspectivas. Entre elas, Roberto Bolaño cria uma saborosa paródia do "Decálogo do perfeito contista", de Quiroga (para alguns), com o título de "Conselhos sobre a arte de escrever contos" (2006, 324-325) ${ }^{44}$. Já no primeiro, dos 12 conselhos que a integram, observa-se a nota irônica da advertência, persistente no decorrer das "orientações": nunca se deve abordar os contos "um a um", pois, pode-se "estar escrevendo o mesmo conto até o dia de sua morte"; na

\footnotetext{
39 Op.cit., p. 91.

${ }^{40}$ Op.cit., p. 99.

${ }^{41}$ Op.cit., p. 91.

42 Op.cit., p. 91.

43 Op.cit., p. 100.

${ }^{44}$ Essa paródia pode remeter a inúmeros autores latino-americanos, que dão conselhos para futuros escritores. Carlos Fuentes, Juan Rulfo, Isabel Allende, Rosa Montero, Vargas Llosa etc. constituem alguns dos que continuam a tradição americana e europeia, na qual se incluem Poe e Tchekhov (se considerarmos as recomendações inseridas em sua correspondência), de propor "normas" de criação literária ou dar conselhos a novos autores.
} 
segunda recomendação, insinua-se uma possível saída para a anterior: o melhor seria escrever "de três em três ou de cinco em cinco" contos, caso haja "energia suficiente" "de nove em nove" ou "de "quinze em quinze". Tais conselhos preparam os que aqui interessam, a saber, o nono, exposto após a indicação de leitura de determinados autores: "A verdade da verdade é que com Edgar Allan Poe todos teríamos de sobra" e o décimo: "Pensem no item número nove. Pensem e reflitam. Ainda tem tempo. Deve-se pensar no nove. Se for possível: de joelhos". Por fim, o ficcionista contempla o autor russo com sua 12a. sugestão (ou ordem?), depois de elencar, na 11a., obras a serem visitadas: "Leiam estes livros e leiam também Tchekhov e Raymond Carver, um dos dois é o melhor contista que nos deu este século". Não importa aqui se Bolaño não escreve à maneira de Poe ou Tchekhov ou se há tom irônico (a interpretar...) ou respeito ao deixar para o leitor a escolha de um dos autores. Importa, sim, seu tributo a ambos. Importa que, até para reverter, parodiar e reelaborar a tradição, é preciso reconhecê-la e Bolaño o faz, a seu modo. Importa, ainda, o olhar sutil de reunir, no final, Tchekhov e Carver.

Não por acaso, Raymond Carver é considerado por parte da crítica "[...]Tchekhov americano". É conhecido seu apreço pelo ato de criar do escritor que lhe rendeu o epíteto ${ }^{45}$, pois, na busca de capturar o banal, $\mathrm{O}$ cotidiano, na prosa enxuta que o consagrou na literatura contemporânea, o autor russo teve papel expressivo. Aliás, Carver dedicou uma narrativa à morte de Tchekhov ("Errand") e jamais negou sua admiração por ele:

Anos atrás li uma coisa numa carta de Tchekhov que me impressionou. Era um conselho para um de seus muitos correspondentes, e dizia mais ou menos o seguinte: Amigo, você não precisa escrever sobre gente extraordinária que realiza feitos extraordinários e memoráveis. (Entendam que na época eu estava na faculdade e lia peças sobre príncipes, duques e sobre a derrubada de reinos. Buscas do cálice sagrado e coisas do gênero, grandes façanhas com o objetivo de pôr os heróis em seus devidos lugares. Romances com heróis exagerados e fora da realidade.). Mas ler o que Tchekhov tinha a dizer naquela carta, bem como em outras cartas, e seus contos me levou a ver as coisas de forma diferente. ${ }^{46}$

\footnotetext{
45 Em "A Storyteller's Shoptalk", ensaio no qual Carver discute a questão da forma de escrita de cada autor e de suas próprias dificuldades de criação e leitura, ele declara que tinha, na parede, uma ficha com um fragmento de uma sentença de Tchekhov. Ela dizia: "e subitamente tudo ficou claro para ele". Carver, então, comenta: Eu acho que essas palavras estão prenhes de assombro e possibilidade. Adoro a simplicidade de sua clareza e a insinuação da revelação aí implícita. Há um pouco de mistério também. O que não estava claro antes? Por que é só agora que se torna claro? O que aconteceu? Sobretudo - o que agora? Há consequências como resultado de tais repentinos despertares. Sinto uma profunda sensação de alívio - e de antecipação." New York Times, February 15, 1981 (tradução minha).

${ }^{46}$ CARVER, Raymond - 68 contos de Raymond Carver. (trad. Rubens Figueiredo). São Paulo: Companhia das Letras, 2010. p. 641.
} 
Entende-se, assim, porque a contribuição de Boris Schnaiderman é tão valiosa, quando se atenta para a extensão da força da narrativa russa, justificando-se o desvio em busca de autores-críticos, especialmente os latino-americanos, com o intuito preciso de apontar a enorme importância de Tchekhov, não apenas em si mesma, mas também para a relativização de algumas concepções teóricas de Poe, que, inegavelmente, continuam atuantes em contos de inúmeros ficcionistas, mas não em todos. $O$ conhecimento do autor russo amplia e diversifica a apreensão do relato breve da modernidade até nossos dias. Logo, o desvio, que contempla a leitura dos parceiros (latino-) americanos, procurou acentuar o valor da tradução da obra de Tchekhov no Brasil e, ao lado dele, o de vários contistas russos que alargaram as perspectivas sobre tal questão. Nesse sentido, a crítica literária tem imensa dívida para com Boris Schnaiderman, que, ultrapassando o trabalho tradutório, insere-se na cadeia crítica representada, entre outros, por Quiroga, Cortázar e Piglia (cujos textos ele conhecia) - e autores que colaboraram com a divulgação da teoria do conto nos meios acadêmicos brasileiros, indo, frequentemente, além deles.

Enfim, é possível estabelecer na produção tradutória e crítico-analítica de Schnaiderman, a respeito da presença do conto russo no Brasil, uma analogia com a visão do conto em Poe e, depois, em Piglia, pois, há em tal produção duas elaborações que correm subjacentes: uma é a do trabalho de tradução das narrativas; outra é a do trabalho teórico que vai se construindo ao lado da primeira e se articulando, discretamente, nos "interstícios" dela, já que se institui um jogo interpretativo necessário não só ao ato tradutório, mas também à percepção da teoria imanente de tais narrativas. Há uma estratégia ao expor a tradução de "O senhor Prokhartchin" e, a seu lado, o subsídio crítico-teórico que o texto de Dostoivéski transmite para a contística moderna, ou seja, embora considerado "conto", ele permite a coexistência de formas literárias e sentidos distintos, sem a delimitação de fronteiras estritas. Na mesma direção, o posfácio de $A$ dama do cachorrinho e outros contos, - a um tempo, conciso, claro e complexo - lega ao público brasileiro o perfil do texto curto de Tchekhov, aponta aspectos importantes da literatura russa e, sobretudo, dialoga com críticos-escritores fundamentais (Poe e, mais recentemente, Cortázar), ressaltando traços peculiares do autor russo, no conjunto de sua fragmentada e "epistolar" teoria do conto, e sublinhando que, se aí há pontos de convergências entre ele e Poe, há também subversões fundamentais, sobretudo, em relação aos desfechos de suas ficções breves.

A homenagem a Schnaiderman acaba se estendendo aos grandes tradutores-críticos, que, para além da luta silenciosa com as palavras, constroem "em segredo", como diria Piglia, uma segunda batalha, a da busca de formas literárias que se agregam a teorias e nos ajudam a pensar textos oriundos de outras margens. A dívida para com Schnaiderman torna 
viva sua lembrança: não parece morrer quem intermediou marcas tão expressivas para amplitude e absorção do outro na cultura brasileira. E, aqui, mais uma frase de Guimarães Rosa, no mesmo discurso de posse mencionado no início, vem colaborar com o encerramento deste artigo, pois ela se adequa à sensação de permanência do tradutor, ensaísta, crítico e professor Boris Schnaiderman entre nós: "Mas - o que é um pormenor de ausência. Faz diferença?", reiterando-se o encanto de uma presença que persiste. 